\title{
ПОНЯТТЯ САМООРГАНІЗАЦІЇ НАВЧАННЯ У КОНТЕКСТІ ПРОФЕСІЙНОЇ ПІДГОТОВКИ МАЙБУТНІХ ВИКЛАДАЧІВ ХОРЕОГРАФІЧНИХ ДИСЦИПЛІН
}

У статті розкривається загальнонауковий зміст поняття “самоорганізаиія особистості” та висвітлюється його специфіка в контексті професійної підготовки бакалаврів хореографії у педагогічних ЗВО. Визначено, шуо самоорганізація власної навчальної діяльності може виступати основою особистісноспрямованої програми становлення й розвитку студентів шляхом формування індивідуального навчального простору, самостійного планування та інтегрування змісту освіти, здійснення моніторингу, контролю й оцінки результативності власної навчальної діяльності, окреслення перспектив подальшого розвитку в особистісному і професійному напрямах.

Ключові слова: навчальна діяльність; самоорганізачія; програма розвитку; самостійність; індивідуальний навчальний простір; професійна підготовка; викладач хореографічних дисциилін.

Jim. 11.

Kseniya Korotkevych, Postgraduate Student, Mykhaylo Drahomanov National Pedagogical University, Kyiv

\section{THE SELF-ORGANIZATION CONCEPT IN THE COURCE OF PROFESSIONAL TRAINING OF FUTURE TEACHERS OF CHOREOGRAPHIC SUBJECTS}

The article deals with the general scientific content of the concept of the self-organization of the individual and highlights its particular characteristics in the context of complex professional training of Bachelors in choreography at teacher's training higher educational establishments. The universality and procedural nature of the phenomenon are reflected by intrinsic features of self-organization. The article traces the interaction of processes of self-organization which results in qualitative changes and transformations, appearance of new properties and features.

These phenomena reflect the role of the individual as a participant or an organizer of certain processes that take place, in particular, in the learning environment. These phenomena are studied in the field of social sciences, pedagogy and psychology. The teacher's training field dwells on the importance of the qualities necessary for a future teacher such as the ability of self-development and self-organization, search creativity and self-improvement. The self-organization in the individual's education in the process of special training can be the basis of an individually directed program of formation and development of students by forming an individual educational space. Selforganization of student's educational work is considered to be a complex, motivated and independent activity, aimed at maximizing the effective assimilation and creative application of relevant professional knowledge, skills and competence.

The educational process of future teachers of choreographic courses requires mastering the content of the core subjects, the subjects included in the curriculum of art training of the specialists as well as the subjects of the elective part in the system of educational and vocational training. In addition, the training given in the article, involves the constant and purposeful development and improvement of the professionally necessary physical features of the young dancers acquired through regular trainings and rehearsals included in the artistic part of the curriculum.

The successful training of the students in choreography in the teacher's training higher educational establishments based on self-organization is determined by the ability to provide personal self-regulation, sustainable and purposeful learning performance, physical and mental activities. The skills of self-organization in the educational activity allow students of choreography to organize and carry out planning, draw up the curriculum, monitor and control of the educational activity on their own, as well as to determine the prospects of further development in professional and personal ways. The educational self-organization in the context of professional training of the teachers of choreography has got important functions, namely didactic, educational and managerial functions.

Keywords: an educational activity; self-organization; vocational training; a teacher of choreographic courses; independence; individual learning space; professional training; a teacher of choreographic disciplines.

П остановка проблеми. Поняття самоорганізації сьогодні вивчається у контексті процесів, що відбуваються у природі, суспільстві, виробництві, людській діяльності та ін. Останнім часом до феномена самоорганізації привернута активна увага науковців у галузі психології, а також теорії та практики педагогіки і психологї̈ навчання суб’єктів освіти. 


\section{ПОНЯТТЯ САМООРГАНІЗАЦЇ̈ НАВЧАННЯ У КОНТЕКСТІПРОФЕСІЙНОӤПІДГОТОВКИ МАЙБУТНІХ ВИКЛАДАЧІВ ХОРЕОГРАФІЧНИХ ДИСЦИПЛІН}

Аналіз основних досліджень. Науковий зміст поняття “самоорганізація” останнім часом все більше цікавить представників різних галузей знань (В. Арюткін, Ю. Бабанський, Л. Ващенко, Н. Гишка, В.Горбач, О. Демченко, С.Котова, Т. Лаврик, Є. Мегель, М. Реунова, Ю. Цагареллі, Яо Ямін та ін.). Проте недостатньо дослідженою поки що залишається проблема визначення сутності самоорганізації навчання у процесі професійної підготовки бакалаврів хореографічного мистецтва у педагогічних ЗВО. Висвітлення цього питання $\epsilon$ метою пропонованої статті.

Виклад основного матеріалу. Поняття самоорганізації універсально пов'язане 3 процесуальною природою дії, що відбувається у будь-якій сфері. Процеси, які протікають у певний період часу, підрозділяються на ті що:

- можуть самі собою організовуватися;

- організуються шляхом спрямованого впливу ззовні;

- змішаного типу.

Отже, в основі різноманітних процесів лежить певна організація (самоорганізація), дія, часовий проміжок, а також зміни, що простежуються від початку процесу до його кінця. Зафіксовані у процесі зміни (результати) відображають якісні характеристики процесу: спрямованість, ефективність, етапність, змістовність та ін. У контексті цього важливо з'ясувати сутність поняття “процес".

Унаслідок всезагального іводночас конкретизованого формату, значення поняття “процес" ученими трактується доволі по різному. Так, процес розумісться як ланцюг послідовних та впорядкованих дій або змін у предметно-часових вимірах, за рахунок реалізації яких досягається певний результат та з'являються нові якості, характеристики, ознаки у певній сфері діяльності. Процесуальність зазвичай демонструє реальні або приховані дії, а також їх наслідки для подальшого розвитку. В контексті різних теорій систем процес трактується як рух або видозмінення системи, стійка і цілеспрямована сукупність пов'язаних перетворювальних дій.

Науковці зазначають, що процеси бувають організованими (кимось або чимось) та самоорганізованими у часі і просторі. Організацію дослідники розуміють як “процес поділу, групування та координації робіт, видів діяльності i ресурсів для досягнення поставлених цілей. Реалізація функції організації здійснюється у процесі організаційної діяльності" [10]. Організаційна діяльність реалізується на основі таких чинників, як об’єднання та спрямування певних процесуальних елементів у цілісне явище, струнку та продуктивну систему. В галузі соціальних наук, педагогіки і психології поняття “організація” i “процес” зазвичай пов'язують 3 категоріями “навчання”, “навчальний процес”.

У педагогічному словнику навчання визначається як “цілеспрямований процес передачі засвоювання знань, умінь, навичок і способів пізнавальної діяльності людини, виконує центральну функцію у розумовому розвитку й підготовці учнів до праці” $[3,22]$. Як процес, навчання відображає спеціалізовані види і форми взаємодії суб'єктів освіти з передачі і засвоєння соціально-історичного досвіду, закодованого у систему наукових знань, явищ культури та суспільної свідомості. Навчання базується, 3 одного боку, на організаційно-викладацькій діяльності вчителя, яка спрямована на планування, реалізацію, керівництво та оцінювання змісту освіти і навчальних досягнень учнів, а також формування певних якостей, властивостей особистості. 3 іншого боку, процес навчання неможливий без діяльності того, хто навчається, а отже - здобуває наукові знання та збагачує емпіричний досвід. Зазначимо, що навчання може бути організованим або здійснюватися шляхом самоосвіти (самоорганізації).

У педагогічних науках підкреслюється значення таких властивостей особистості майбутнього вчителя, як здатність до саморозвитку, самовдосконалення, творчого пошуку. Самоорганізація власної навчальної діяльності у процесі фахової (професійної) підготовки може виступати основою особистісноспрямованої програми становлення й розвитку студентів шляхом формування індивідуального навчального простору, процесу. Здатність до самоорганізації у навчальному процесі 3ВО та самостійних формах і видах навчальної роботи (самопідготовки) фокусується, на думку дослідників (В. Краєвський, 3. Петрасинський та ін.), на розв'язання питань розробки індивідуально-орієнтованих цілей і завдань навчання кожного окремого студента, спрямування його освіти та самоосвіти в контексті формування особистісних і професійних якостей.

Алгоритм самоорганізації особистості у навчанні ще не до кінця вивчений, оскільки є складним психологічним утворенням, що базується, зокрема, на таких характеристиках індивідууму, як відповідальність, самостійність, дисциплінованість, активність, а також уміннях планувати, коригувати та контролювати власну навчальну діяльність. Самостійна організованість студента яскраво виявляється тоді, коли потрібно одночасно і у певний проміжок часу опановувати 


\section{ПОНЯТТЯ САМООРГАНІЗАЦІЇ НАВЧАННЯ У КОНТЕКСТІПРОФЕСІЙНОЇПІДГОТОВКИ МАЙБУТНІХ ВИКЛАДАЧІВ ХОРЕОГРАФІЧНИХДИСЦИПЛІН}

зміст різних дисциплін - як теоретичних, так i практичних. Тому самоорганізацію навчальної роботи студентів можна розглядати як складну та водночас цілісну самостійну діяльність, спрямовану на максимально ефективне засвоєння і творче застосування необхідних фахових знань, умінь і навичок.

Як правило, підготовка фахівців педагогічного профілю спрямована на озброєння студентів потрібною й актуальною інформацією (знаннями), формування визначених фахових компетентностей i практичних умінь та навичок залежно від специфіки майбутньої діяльності вчителів. У галузі професійної підготовки викладачів хореографічних дисциплін до перерахованого вище додається ще сфера розвитку і удосконалення фаховонеобхідних фізичних даних молодих танцівників за рахунок постійних вправлянь, тренувань, репетицій на дисциплінах творчо-виконавського циклу.

Підготовка педагогічних кадрів у галузі хореографічного мистецтва обіймає дисципліни нормативного блоку (українська мова, історія української державності, філософія, іноземна мова, етика та естетика, музична інформатика, екологія, безпека життєдіяльності), предмети, що входять до циклу професійної підготовки (практикум 3 хореографічної підготовки: постановка концертних номерів, теорія і методика викладання (ТМВ) класичного танцю, ТМВ народно-сценічного танцю, ТМВ українського народного танцю; вітчизняна та всесвітня історія хореографії; зразки ансамблевої хореографіi), а також дисципліни вибіркової частини самостійного вибору ЗВО (психологія, педагогіка, історія педагогіки, методика роботи 3 дитячим хореографічним колективом) та вільного вибору студента (теорія і практика хореографічного виконавства, основи бальної хореографії, ансамблі, основи сучасної хореографії, педагогічна творчість, культурологія, музична психологія, режисура хореографії, основи музично-теоретичної підготовки, основи дуетної техніки та багато інших). Крім того, важливою складовою підготовки бакалаврів хореографії виступає практична підготовка студентів (культурологічна, організаційно-виховна, навчальна педагогічна, виробнича).

З викладеного стає зрозумілим, що опанування змісту багатьох навчальних дисциплін потребує активної самостійної і спрямованої діяльності студентів на основі самоорганізації навчання. Означена діяльність потребує формування у суб'єктів освіти відповідних умінь самоорганізації, які, зі свого боку, базуються на певних теоретичних знаннях. “За умови сформованості у студентів необхідних умінь і навичок вони зможуть успішно аналізувати завдання та умови навчання, раціонально планувати та грамотно організовувати свій навчальний простір, адекватно оцінювати i своєчасно коригувати або удосконалювати хід роботи, потім підвести підсумки своєї навчальної діяльності, тобто зможуть ефективно ним управляти", - вказує у своєму дослідженні Яо Ямін $[11,41]$.

Отже, успішне навчання на основі самоорганізації студентів-хореографів у педагогічних 3ВО визначається уміннями забезпечувати особистісну, стабільну протягом певного періоду часу навчальну саморегуляцію, працездатність і продуктивність, фізичну і розумову активність тощо. Необхідні уміння самостійно організовувати себе у навчальній діяльності формуються на основі визначення алгоритмів дій, способів їх реалізації. Основою для їх формування виступають усі засвоєнні студентами загальнонаукові і спеціальні (фаховоспрямовані) знання, уміння й навички, а також отриманий художній і життєвий досвід. Крім того, важливого значення у контексті сказаного набуває психічна активність суб'єкта мистецької освіти, його вольові якості.

Аналізуючи професійну підготовку майбутніх викладачів хореографічних дисциплін, можемо виокремити такі необхідні уміння: загальні (здатність сприймати і осмислювати інформацію, володіти способами пізнавальної діяльності: аналіз, логічне упорядкування, систематизація, класифікація, порівняння, узагальнення та ін.); спеціальні, що зумовлені специфікою навчальної діяльності та їі спрямованістю на майбутню професію (художньо-виконавські, артистичні, педагогічні та ін.).

Сучасні дослідження дають підставу констатувати, що уміння навчальної самоорганізації студентів-танцівників слід розглядати як особистісне утворення, що забезпечує взаємозв'язок усіх видів і форм навчання через розуміння їх професійної значущості для особистості та смислової спрямованості на педагогічно-хореографічну діяльність. Уміння самоорганізації навчальної діяльності у підготовці бакалаврів хореографії допомагають їм самостійно організовувати та здійснювати планування, інтеграцію змісту, моніторинг, контроль навчальної діяльності, оцінити іiі результативність і окреслити перспективи подальшого становлення фахівців в особистісному та професійному напрямах. Професійна підготовка майбутніх викладачів хореографічних дисциплін обіймає певні блоки 


\section{ПОНЯТТЯ САМООРГАНІЗАЦІЇ НАВЧАННЯ У КОНТЕКСТІПРОФЕСІЙНОЇПІДГОТОВКИ МАЙБУТНІХ ВИКЛАДАЧІВ ХОРЕОГРАФІЧНИХ ДИСЦИПЛІН}

навчальних дисциплін теоретичного (наукового), методичного та практично-виконавського характеру. Отже, підготовка фахівців вимагає комплексного підходу на основі інтеграції та міждисциплінарних зв'язків предметів різних циклів, а також особистісного навчального досвіду суб'єктів мистецької освіти. Цілком природно, що сприйняття та засвоєння такої кількості необхідної інформації, іiї практичного застосування і умінь потребує формування у студентів умінь самоорганізації навчальної діяльності.

Конкретизуючи поняття навчальної самоорганізації в контексті професійної підготовки бакалаврів хореографії, доцільно визначити їхнє функиіональне значення для підвищення якості освіти майбутніх фахівців. Цю проблему у більш широкому значенні вивчали Ю. Бабанський, Л. Ващенко, Н. Гишка, М. Демченко, М. Федорова, Л. Якушкіна та ін.

Уміння ефективно самостійно організовувати навчання позитивно впливає також на формування індивідуальних психічних якостей майбутніх фахівців, має певне виховне значення, оскільки сприяє розвитку відповідальності, сумлінності, дисциплінованості, мобільності, наполегливості та працездатності. У контексті цього можна актуалізувати розвивально-виховну функцію навчальної самоорганізації.

Важливість формування умінь навчальної самоорганізації обумовлюється потребою удосконалення та підвищення ефективності навчання майбутніх фахівців. Цим і пояснюється дидактична функція та спрямованість самоорганізації. Навчання бакалаврів-хореографів виступає основним процесуальним змістом їхньої діяльності у ЗВО. Навчальний процес як розгорнута у часі дія, спрямовані на якісні перетворення та зміни в усіх складових (компонентах) цього складного і комплексного феномена, реалізується у різних видах пізнавальної та творчо-виконавської діяльності суб'єктів мистецької освіти, у тому числі самостійно організованої.

Відсутність умінь організовувати себе в процесі навчання негативно впливає на якісні та кількісні результати, гальмує особистісний і професійний розвиток студентів. Натомість дидактична спрямованість навчальної самоорганізації може забезпечити максимальну індивідуалізацію, безперервність та систематичність освітнього процесу у найбільш продуктивних, оптимальних та ефективних формах і видах навчальної та творчо-виконавської діяльності студентів.

Важливою функцією навчальної самоорганізації виступає також управлінсько-контрольна. Ця теза підтверджується даними про те, що успішний навчальний процес потребує активного, постійного контролю та управління 3 боку студента. У проєкції на майбутню професійну діяльність можна говорити про актуальність формування відповідних компетенцій у процесі підготовки бакалаврів хореографії. Управлінсько-контрольна функція майбутнього керівника хореографічного колективу реалізується через налаштованість на постійну взаємодію з вихованцями, організацію їх навчальної і творчо-виконавської діяльності.

Висновки. Таким чином, у статті було визначено сутність феномена самоорганізації у контексті комплексної професійної підготовки майбутніх викладачів хореографічних дисциплін у педагогічних 3ВО, а також розкрито перспективи дослідження функціональних особливостей навчальної самоорганізації суб'єктів мистецької освіти у світлі сучасних тенденцій розвитку галузі.

\section{ЛІТЕРАТУРА}

1. Ващенко Л.С. Уміння вчитися - ключова компетентність учнівської молоді сучасного інформаційного суспільства. Інформаційні технології $і$ засоби навчання. 2014, №5. Т. 43. C. $1-14$.

2. Гишка Н. Учіння - невід'ємна складова майбутнього спеціаліста. Початкова освіта. 2011, №1. С. 38-39.

3. Гончаренко С.У. Український педагогічний словник. Київ, 1997. 375 с.

4. Горбач В. Самостійна робота студентів як основа самоорганізації та розвитку особистості. Гірська школа Українських Карпат. 2015. №1213. C. $184-186$.

5. Граф В., Ильянов И., Ляудис М. Основы самоорганизации учебной деятельности и самостоятельная работа студентов: учебнометодическое пособие. Москва, 1981. 80 с.

6. Демченко О. Загальнопрофесійні функції самоорганізації педагога. Проблеми підготовки сучасного вчителя : зб. наук. праць Уманського держ.пед.ун-ту імені Павла Тичини. Умань, 2012. Вип.5. Ч.2. С. 34-40.

7. Лаврик Т.В. Обгрунтування складових інтегрального критерію здатності студентів до самоорганізації й самоуправління. Вісник Чернівеџького університету. Серія "Педагогічні науки”. Вип. 183. Ч. IV. С. 70-75.

8. Мегель Є. Самоорганізація учіння студентів у проектно-технологічній підготовці як засіб їхнього особистісного росту. Наукові записки Тернопільского національного педагогічного 
університету. Серія Педагогіка. Тернопіль, 2007. №8. C. 94-98.

9. Навчальні матеріали онлайн. Самоорганізація. URL: http://pidrucniki/com (дата звернення 19.12.2019).

10. Самоорганизация и самоуправление.URL: http://studopedia.info/3-33532/html (дата звернення 04.01.2020).

11. Яо Ямін. Методика самоорганізації навчального простору майбутніх викладачівмузикантів у педагогічних університетах України: дис ... канд.пед.наук : 13.00 .02 . НПУ ім. М.П. Драгоманова. Київ, 2018. 241 с.

\section{REFERENCES}

1. Vashenko, L.S. (2014). Uminnya vchitisya klyuchova kompetentnist uchnivskoyi molodi suchasnogo informacijnogo suspilstva [The ability to learn is a key competence of the students in the modern information society]. Information Technologies and Yeaching Aids. No. 5. Vol. 43. pp. 1-14.[in Ukrainian].

2. Gishka, N. (2011). Uchinnya - nevidyemna skladova majbutnogo specialista [Learning is an integral part of the future specialist]. Primary Education. Vol.1.pp. 38-39.[in Ukrainian].

3. Goncharenko, S.U. (1997). Ukrayinskij pedagogichnij slovnik [Ukrainian pedagogical dictionary]. Kyiv, 375 p. [in Ukrainian].

4. Gorbach, V. (2015). Samostijna robota studentiv yak osnova samoorganizaciyi ta rozvitku osobistosti [Independent work of students as a basis of selforganization and personal development]. Mountain School of the Ukrainian Carpathians. Vol.12-13. pp. 184-186. [in Ukrainian].

5. Graf, V., Ilyanov, I. \& Lyaudis, V. (1981). Osnovy samoorganizacii uchebnoj deyatelnosti i samostoyatelnaya rabota studentov : uch.-met.pos. [Fundamentals of self-organization of educational activities and independent work of students: study guide]. Moscow, 80 p. [in Russian].

6. Demchenko, O. (2012). Zagalnoprofesijni funkciyi samoorganizaciyi pedagoga [General professional functions of teacher's self-organization]. Issues of modern teacher training:scientific study manual of Uman State Pedagogical University named after Pavel Tychyna. Uman, Vol.5. issue.2. pp.34-40. [in Ukrainian].

7. Lavrik, T.V. (2010). Obgruntuvannya skladovih integralnogo kriteriyu zdatnosti studentiv do samoorganizaciyi i samoupravlinnya [Feasibility demonstration of the integral criterion of students' ability to self-organization and self-management]. Chernivtsi University Press "Pedagogical Sciences”. Vol.183. Part. IV. pp. 70-75. [in Ukrainian].

8. Megel, Ye. (2007). Samoorganizaciya uchinnya studentiv u proektno-tehnologichnij pidgotovci yak zasib yihnogo osobistisnogo rostu [Self-organization of student learning in design and technological training as means of their personal growth]. Scientic Newsletter of Ternopil Pedagogical University. Pedagogy series. Ternopil. Vol.8. pp. 94-98.

9. Navchalni materiali onlajn Samoorganizaciya [Learning Material Online. Self-organization]. Available at: http://pidrucniki/com. [in Ukrainian].

10. Samoorganizaciya i samoupravlenie [Selforganization and self-management]. Available at:http:/ /studopedia.info/3-33532/html. [in Russian].

11. Yao Yamin. (2018). Metodika samoorganizaciyi navchalnogo prostoru majbutnih vikladachivmuzikantiv u pedagogichnih universitetah Ukrayini [Methods of self-organization if educational space of future music teachers in pedagogical universities in Ukraine]. Candidate's thesis. Ministry of Education and Science of Ukraine. National Pedagogical Drahomanov University Press. Kyiv. 241 p. [in Ukrainian].

Стаття надійшла до редакції 26.06.2020

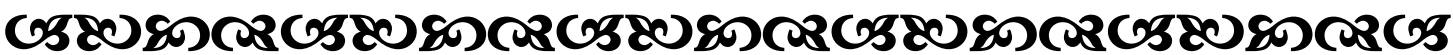

“3 усіх творінь найпреқрасніше - людина, що отримала прекрасне виховання”. Enikmem давньогрецький білособ

“У тому, щуо стосується майбутнъого, я повторюю одне: за що б ви не взялися, головне - будвте віддані своїй справі до кіния. Не обов'язково досягати якогось зоряного успіху, але бути чесним перед самим собою в обраній проббесіӥ-обов'язково”.

\section{G58080.2058080}

